\title{
Kendala Pengawasan Melekat Bahan Habis Pakai Pasien Gakin (Unit Rawat Inap RS Persahabatan Tahun 2006)
}

\author{
Ernawaty*
}

\begin{abstract}
Abstrak
Pelaksanaan pengawasan atasan langsung (waskat) dalam penggunaan bahan habis pakai/obat dan pemberian obat untuk pasien gakin adalah sangat penting. Tujuan penelitian ini adalah mengidentifikasi berbagai komponen unit pengawasan yang lemah dan berbagai faktor yang berhubungan meliputi struktur organisasi, kebijaksanaan pelaksanaan berikut tindakan koreksi terhadap penyimpangan. Metode penelitian yang digunakan adalah metode kualitatif dengan menggunakan sumber data primer dan sekunder, yang meliputi pengamatan pasif, telaah dokumen dan wawancara mendalam terhadap berbagai informan yang terkait. Untuk menilai keabsahan data dilakukan kembali triangulasi sumber, member chek, diskusi dengan teman sejawat dan melakukan analisis kasus negatif. Hasil penelitian menemukan kendala dalam proses pelaksanaan pengawasan melekat pada penggunaan bahan habis pakai/obat dan pemberian obat bagi pasien gakin. Kendala tersebut ditemukan pada sarana dan sasaran pengawasan (komponen-komponen unit), kepemimpinan, budaya pengawasan sampai dengan tindakan koreksi. Disarankan melakukan peninjauan kembali berbagai komponen unit sarana dan sasaran pengawasan dengan meningkatkan pengetahuan dalam manajemen pengawasan. Meteapkan budaya pengawasan sampai dengan tindakan koreksi serta melakukan rekonsiliasi/ kerja sama antara Instalasi Rawat Inap, Instalasi Penyelesaian Piutang (/IPS) dan Apotik secara teratur.
\end{abstract}

Kata kunci : Pengawasan melekat, bahan habis pakai/ obat pasien gakin

\begin{abstract}
The implementation of direct supervision in consumables/drugs and medication for poor patient is considered as of highly important. The objectives of the research are to identify weak point in supervision unit components and related factors including organizational structure, implementation policy and corrective action. The study used qualitative method using both primary and secondary data including passive observation, document review, and in-depth interview to key informants. To validate the data, source triangulation was used as well as member checking, peer discussion, and negative case analysis. The study found that obstacles in supervision are related to facility and supervision targets (unit components), leadership, supervisory culture, and improper corrective action. It is suggested to review unit components related to facility and supervision target by improving knowledge on supervision management. It is also suggested to establish positive supervision culture including corrective action and collaboration between units and dispensary in a regular way.
\end{abstract}

Key words : Direct supervision, consumables, poor families

*Staf Dinas Kesehatan Kabupaten Bone Bolango Propinsi Gorontalo 
Krisis ekonomi yang dialami Indonesia, pada tahun 1998 telah menurunkan kemampuan seluruh lapisan masyarakat yang berakibat penurunan akses terhadap pelayanan kesehatan dan memicu krisis kesehatan. Penduduk miskin yang sebelumnya sudah tidak mampu, semakin tidak mampu dan mengalami kesulitan kehidupan. Masyarakat menjadi tidak mampu menyelenggarakan kesehatan bagi diri dan keluarga mereka. ${ }^{1}$ Sejak itu, masyarakat miskin mulai mendapatkan pelayanan kesehatan melalui program Jaring Pengaman Sosial Bidang Kesehatan (JPS BK), dengan dana pinjaman luar negeri. ${ }^{2}$

Paragdima sehat yang mulai disosialisasikan tahun 1999, membangkitkan gagasan tentang subsidi masyarakat miskin secara konsisten. ${ }^{3}$ Pada tahun 2002, pemerintah memenuhi kebutuhan dasar hidup masyarakat miskin tersebut melalui program Penanggulangan Dampak Pengurangan Subsidi Energi Bidang Kesehatan dan Kesejahteraan Sosial (PDPSE BK dan KS). ${ }^{4}$ Pada tahun 2004, pemerintah lebih memfokuskan tanggung jawab dan komitmen pemenuhan kebutuhan dasar hidup masyarakat miskin melalui Sistem Jaminan Sosial Nasional. 5

Konferensi Nasional Penanggulangan Kemiskinan dan Pencapaian Tujuan Milenium sepakat melaksanakan pengawasan dan pengendalian yang baik serta melakukan pemantauan dan evaluasi dengan indikator yang jelas dan terukur. ${ }^{6}$ Dengan demikian, dana jaminan pelayanan kesehatan masyarakat miskin dapat dikelola oleh rumah sakit secara profesional dengan pengawasan yang ketat dan akuntabel. Rumah sakit juga harus dikelola dengan prinsip efisiensi dan efektif. Pengawasan yang merupakan salah satu fungsi manajemen digunakan untuk meningkatkan efisiensi berbagai kegiatan atau program unit pelayanan di rumah sakit. ${ }^{7}$

Pelaksanaan kegiatan program masyarakat miskin menghadapi berbagai hambatan akibat pengawasaan yang lemah. Hal tersebut antara lain terlihat pada laporan fiktif, mark up bahan habis pakai, imbalan tindakan medis dan keperawatan yang berakibat tindakan berlebihan. Berbagai komponen biaya seperti biaya operasional, bahan habis pakai dan jasa dilaporkan menjadi relatif lebih tinggi. ${ }^{4}$ Tarif rumah sakit klas III untuk masyarakat miskin ternyata lebih besar daripada tarif kelas I untuk masyarakat umum. Di RS Persahabatan, terjadi peningkatan biaya rata-rata kebutuhan pasien gakin rawat inap menjadi Rp 329.224,99/ hari/ pasien. Biaya tersebut relatif lebih rendah daripada biaya rata-rata kebutuhan rawat inap pasien gakin di RSU Dr.Agoesdjam Kabupaten Ketapang Kalimantan Barat (Rp 441.127,00 / hari/ pasien. ${ }^{4}$ Namun, berdasarkan analisis data susenas biaya rata-rata kebutuhan awat inap pasien gakin adalah Rp 100.000,00/ hari/ pasien.

Di Rumah Sakit Persahabatan (RSP), pelayanan kesehatan masyarakat miskin telah dilakukan pada
Instalasi Pelayanan Sosial. ${ }^{8}$ Untuk itu, sejak awal tahun 2005, telah dilakukan penataan alur proses administrasi dan mekanisme kontrol penyelenggaraan pelayanan masyarakat miskin. Pengawasan dilakukan mulai dari penerimaan pasien, pembuatan resep obat dan bahan habis pakai sampai dengan monitoring kasus katastropik (pasien dengan biaya tinggi) di unit rawat inap. Pengawasan dilakukan oleh semua instalasi terkait seperti unit pelayanan sosial, rawat inap, penunjang, farmasi dan apotik, untuk mewujudkan pelayanan kesehatan yang rasional, bermutu dengan biaya yang terkendali. Pengawasan dan pengendalian yang kurang akan mengakibatkan tagihan yang besar dan dapat menyebabkan bad-debt (saldo piutang tak tertagih) bagi pihak rumah sakit. ${ }^{8}$

Pengawasan pelayanan tersebut ternyata belum optimal, terbukti masih ditemukan kasus resep obat/ bahan habis pakai pada unit rawat inap yang tidak ditanda tangani oleh dokter pemeriksa. Beberapa pasien rawat inap tidak menerima semua obat yang diresepkan. Bahan habispakai/obat pasien rawat inap gakin yang kabur, meninggal atau berlebihan tidak seluruhnya dikembalikan ke apotik atau bagian farmasi. Hal tersebut berpengaruh terhadap rasionalitas dan kelayakan medis setiap dokumen terhadap prosedur dalam pembayaran pelayanan yang diberikan rumah sakit. Seperti terlihat pada kasus tanpa bukti obat dengan pembayaran dipending pada tahun 2005, triwulan III (1 kasus senilai Rp. 5.525.300) dan triwulan IV (14 kasus senilai Rp. 14. 809.000).

Penelitian ini bertujuan mengidentifikasi berbagai komponen unit pengawasan yang lemah, berbagai faktor yang berhubungan dan tindakan koreksi terhadap penyimpangan yang terjadi. Hasil penelitian ini diharapkan menjadi bahan pertimbangan proses pengawasan penggunaan bahan habis pakai/obat bagi pasien gakin di unit rawat inap khususnya di RS Persahabatan.

\section{Metode}

Penelitian ini menggunakan metode penelitian deskriptif-kualitatif, dengan mengamati proses yang dilakukan oleh sekelompok orang. Pengumpulan data dilakukan dengan tehnik: (1) pengamatan pasif (observation participant pasif), (2) telaah dokumen catatan perawat/petugas tagihan, dan dokumen lain yang berhubungan. (3) wawancara mendalam dari informan/nara sumber terpilih. Penelitian dilakukan oleh peneliti di unit rawat inap RS Persahabatan pada bulan Mei-Juli 2006.

\section{Hasil \\ Struktur Organisasi Unit \\ Struktur organisasi instalasi rawat inap RS}


Persahabatan, berada dibawah kendali Bidang Keperawatan yang bertanggung jawab pada Direktur Utama melalui Direktur Medik dan Keperawatan. Fungsi pengawasan langsung pada pelaksana dan pasien dipegang oleh penanggung jawab ruangan. Dalam uraian tugas pengawasan, kepala instalasi sampai dengan penanggung jawab ruangan bertanggung jawab memantau kegiatan dan melakukan bimbingan. Selain mengawasi kegiatan yang berjalan, mereka juga bertanggung jawab meningkatkan pengetahuan dan keterampilan. Para petugas pelaksana mendapat sosialisasi berbagai program yang dilaksanakan di rumah sakit. Namun, penelitian ini mengungkapkan bawa sosialisasi tidak menyeluruh sampai pada setiap sosialisasi/pre conference, tidak dibuat pedoman tertulis terhadap sosialisasi yang sudah diberikan. Ditemukan beberapa pelaksana yang tidak mengetahui prosedur secara jelas.

Kepala Instalasi Unit Rawat Inap belum sepenuhnya mengupayakan pelaksanaan pelayanan kesehatan masyarakat miskin secara baik. Secara tehnis medis tidak ada perbedaan penanganan pasien, tapi tidak ditemukan dokumentasi penyimpangan dan upaya mencegah penyelenggaraan pelayanan di unit. Dibandingkan dengan pasien umum, jumlah pasien gakin sangat sedikit.

Jumlah pasien gakin $(8,48 \%)$ terlihat jauh lebih rendah daripada pasien umum ( 43,23\%). Namun, pada tahun 2005, 762 pasien rawat inap gakin menghabiskan dana Rp 2.045.269.920,-. Pada proses klaim (pembayaran pihak ketiga, ternyata tidak semua dana tersebut dibayar. Pembayaran 34 kasus senilai Rp 111.428.520,- dipending bahkan klaim 15 kasus senilai Rp 180. 942.190,- tidak dibayar dan menjadi saldo piutang tak tertagih (bad debt) pihak rumah sakit.

\section{Prosedur Kerja}

Unit rawat inap belum merencanakan pelaksanaan pelayanan kesehatan masyarakat miskin. Instalasi rawat inap IRIN A dan IRIN B, mengelola program kesehatan masyarakat miskin di ruang klas III perawatan. Perencanaan kerja unit pada tahun berjalan meliputi pembinaan SDM tentang budaya organisasi; pengembangan jumlah dan kualitas SDM; peningkatan kualitas pelayanan IRIN (BOR, TOI, BTO); perbaikan dan pemeliharaan sarana fisik; prasarana (alat kesehatan, kepe-rawatan, alat medis, alat rumah tangga, alat makan dan ATK) dan survey kepuasan pasien.

Prosedur kerja tindakan keperawatan sudah dijalankan berdasarkan perencanaan kebutuhan pasien yang disebut Strategi Pelaksanaan (SP). Prosedur tersebut dilengkapi dengan perangkat alat yang selalu dibawa pada pasien. Namun, alur/ skema prosedur tindak keperawatan dengan simbol-simbol yang memudahkan pelaksana tidak ditemukan, yang ada hanya tulisan dan alur yang bersifat kegawat-daruratan. Prosedur kerja ditemukan tergantung dengan tulisan ukuran kecil sehingga sulit dibaca. Beberapa ruangan menempelkan prosedur tetap yang terdapat dalam buku Protap Tindakan Umum Keperawatan I-II. Prosedur tetap tersebut dilaminating dan digantung dekat lemari alat atau kereta dorong perangkat alat, tanpa penulisan ulang dengan simbol atau skema.

Sebagian ruangan mengembalikan sisa obat tanpa menggunakan formulir isian, sebagian lagi tidak mengembalikan sisa obat. Tampaknya ada kesepakatan bahwa obat sisa yang dihimpun di ruangan/ di depo obat tersebut digunakan untuk pasien lain yang membutuhkan. Menurut Kepala Instalasi Logistik Farmasi dan Instalasi Pelayanan Sosial, bahan habis pakai yang dihimpun tersebut digunakan untuk pasien baru yang belum mendapatkan jaminan atau yang tidak mempunyai uang. Kebijakan pengembalian sisa obat yang bervariasi dan dengan dokumentasi yang lemah tersebut juga terungkap dalam diskusi kelompok. Dokumen formulir isian pengembalian obat sisa yang diketahui kepala instalasi dan ditemukan di beberapa ruangan.

Pelaksanaan tugas pencatatan dan pelaporan tentang penggunaan bahan habis pakai/obat dan pemberian obat kepada pasien miskin sudah memadai. Meskipun demikian, ada beberapa ruangan yang belum merealisasikannya secara tepat waktu. Hal tersebut mungkin disebabkan oleh rasio pelaksana dan pasien yang tidak seimbang; kondisi pasien gawat darurat yang menuntut perhatian lebih banyak; pelaksana yang tidak dapat mengayut waktu selama di ruangan; dan waktu pencatatan pelaporan yang tidak tepat, antara lain pencatatan pada komputer tentang; keluhan, tindakan, dan pengobatan; kegiatan harian tentang tindakan langsung yang yang dibiayai rumah sakit, kegiatan penunjang dan konsul dokter pada komputer; pengisian papan nama pada tempat tidur pasien.

\section{Petugas Pelaksana}

Petugas pelaksana pelayanan kesehatan penduduk miskin dibina langsung oleh pimpinan/manajer unit setelah kepala instalasi sampai penanggung jawab ruangan rawat inap mendapat sosialisasi pelaksanaan pelayanan yang dilakukan secara periodik. Kepatuhan petugas tidak lagi menjadi masalah dalam pelaksanaan kegiatan keperawatan di Instalasi tersebut. Para pelaksana di beberapa ruangan telah mulai menjalankan kebijakan pengembalian sisa obat.

Para pelaksana kegiatan sudah melakukan penilaan instalasi rawat inap dengan baik. Kepala instalasi rawat inap telah menjalankan fungsi pengawasan dan telah mempunyai jadwal supervisi dan pembinaan personil secara tekis dan sosial. Namun, kepala instalasi belum menjalankan fungsi manajer, terkadang tugas yang dibe- 
rikan hanya diserahkan ke pelaksana. Penanganan lembar kartu pelayanan pasien gakin, berbeda antara satu ruangan dengan ruangan lain, demikian juga kebijakan pengembalian sisa obat. Pimpinan belum optimal mengatur pelaksanaan, penugasan dengan pemberian petunjuk atau prosedur pelaksanaan tugas secara jelas dan mengawasi dan evaluasi petugas. Pengawasan sudah dilakukan, tapi belum membudaya.

\section{Standar dan Prosedur Tetap}

Standar yang sudah ditentukan telah digunakan untuk menilai mutu pelayanan kesehatan masyarakat miskin yang dilakukan dengan perbandingan terhadap standar untuk mengetahui pelaksana yang sesuai tujuan organisasi. Standar permintaan dan resep bahan habis pakai dan obat gakin ditetapkan oleh Dinas Kesehatan DKI Jakarta dengan mengacu obat generik DOEN plus. Pemberian obat oral dan injeksi serta bahan habis ditentukan untuk 3 hari pemakaian Obat dikeluarkan oleh Instalasi Pelayanan Sosial yang melaksanakan pelayanan dalam RS. Merkipun telah ada standar, pelaksana terkadang masih mempertanyakan tentang resep yang tidak seluruhnya dipenuhi. Hal tersebut terungkap dalam diskusi kelompok. Mereka menginginkan standar obat yang sama DPHO yang digunakan oleh askes yang ada dalam daftar dan tidak membingungkan. Menurut kepala instalasi pelayanan sosial (IPP), ada pasien gakin yang mendapat obat non generik karena ada kesepakatan dokter yang merawat dan apotik.

Kinerja pelaksana tentang prosedur keperawatan dan pemberian obat diukur dengan mengacu Prosedur Tetap Tindakan Umum Keperawatan dan Standar Asuhan keperawatan. Kinerja pelaksana dinilai oleh penanggung jawab ruangan dan koordinator asuhan keperawatan, ketika observasi di ruangan atau kegiatan pre conference. Penilaian dilakukan oleh penanggung jawab ruangan dan koordinator asuhan keperawatan berdasarkan laporan yang ada di ruangan yang dapat dijadikan alat ukur hasil kinerja pelaksana. Pengukuran kegiatan dapat dilakukan dengan melihat pencatatan dan pelaporan yang masih banyak penyimpangan. Jika kinerja pelaksana diukur secara sungguh-sungguh, seperti papan nama pasien yang terkadang tidak ditulis sehinga memungkinkan pelaksana kerja yang tidak efisien dan efektif. Penulisan catatan asuhan keperawatan memungkinkan data tidak tercatat sampai dengan tidak diinput setiap hari dengan alasan banyak pekerjaan, tidak ada petugas khusus, kurang pelaksana di ruangan.

Pada observasi dan diskusi kelompok terlihat lembaran tersebut lusuh, banyak coretan, karena tidak tersedia kolom pemberian obat dari apotik. Selain itu, kolom obat tidak lagi dipakai. Juga terungkap bahwasanya lembar kartu dapat tercecer sehingga tidak pada tempatnya. Berbagai cara yang dilakukan makin menambah seme- rawut karena lembar tersebut tidak hanya satu, dan setiap pasien mempunyai catatan berlembar-lembar. Lembar kartu tersebut merupakan pengendali biaya dan pemakaian bahan bahan habis pakai dan obat, juga untuk penagihan kepada pihak ke tiga. Hal tersebut dapat berakibat keraguan terhadap kebenaran data dan berpengaruh terhadap pembayaran penagihan.

\section{Koreksi}

Koreksi yang dilakukan hanya terhadap tata tertib kedatangan/kedisiplinan pelaksana. Langkah ini dilakukan, setelah pimpinan mengetahui penyimpangan yang harus diperbaiki. Pada pelayanan kesehatan masyarakat miskin, koreksi hanya ditemukan pada satu ruangan asisten kepala instalasi. Koreksi dilakukan pada kartu pelayanan pasien gakin yang dianggap merepotkan. Sebelumnya lembar tersebut tertulis pada buku yang dianggap tidak memadai karena sering hilang. Kemudian, lembar kartu pelayanan dijadikan satu dalam map untuk semua pasien yang masih mungkin hilang/ tercecer. Setelah itu, dilakukan koreksi dengan memasukkan ke dalam map tiap pasien yang selanjutnya dijadikan dalam satu folder. Koreksi tersebut membuat lembar kartu aman di dalam map dan pasien dapat membawanya ke instalasi berikutnya.

Koreksi lain yang dilakukan berkaitan dengan penyelenggaraan pelayanan kesehatan masyarakat miskin, juga terlihat pada 1-2 ruangan yang berkaitan dengan dokumentasi pengembalian sisa obat. Sebelumnya, dokumentasi pengembalian sisa obat yang dilakukan pelaksana hanya berupa penulisan di selembar kertas. Ternyata dokumentasi seperti itu tidak memadai dan upaya ini dilakukan pada semua pasien sehingga dilakukan koreksi. Kini, dokumentasi pengembalian sisa obat sudah mempunyai format tersendiri dalam rangka pengembalian sisa obat ke apotik dan diketahui oleh kepala instalasi.

\section{Pembahasan \\ Struktur Organisasi}

Struktur organisasi merupakan piranti pelaksanaan proses kerja agar mampu mengoperasikan volume dan beban kerja untuk mencapai tujuan organisasi. ${ }^{9}$ Pengorganisasian harus memperhatikan dan melaksanakan prinsip-prinsip organisasi yang menyertakan komponen pengawasan yang dievaluasi secara periodik. Penelitian lain menunjukan bahwa dalam struktur organisasi instalasi rawat inap ditemukan perawat pengawas beberapa ruangan dengan proses pengawasan yang tidak sesuai harapan. Hal tersebut disebabkan oleh jumlah dan pendidikan perawat pengawas tidak memadai. Selain itu, karena kurang pengetahuan manajemen pengawasan dan tidak ada umpan balik/ evaluasi oleh atasan sebagai akibat tidak dipahaminya kesulitan di lapangan. Di RS Persahabatan, seorang penanggung jawab di tiap rua- 
ngan dengan fungsi disamakan dengan pengawas perawatan yang berpendidikan akademi keperawatan. Hal tersebut sudah memadai untuk proses pengawasan dan didukung pengetahuan manajemen pengawasan.

Dalam menjalankan tugas-tugas pemerintahan dan pembangunan, biasanya sudah ada kebijakan dan ketentuan perundangan atau peraturan yang harus dijalankan dan biasanya disertai perencanaan kerja yang telah disusun. Walaupun semuanya telah ada, pimpinan harus dapat menetapkan kebijaksanaan menjalankan program dan membuat perencanaan pada setiap program yang dilakukan unit. Pembuatan kebijaksanaan tersebut mungkin dapat dilakukan pimpinan, karena peraturan/ perencanaan sebelumnya masih bersifat umum, atau belum jelas. ${ }^{9}$ Kebijaksanaan pelaksanaan yang dibuat unit berbentuk pedoman untuk membimbing dan mengarahkan dalam langkah-langkah selanjutnya sehingga lancar dan terpadu.

\section{Perencanaan Kerja Unit}

Perencanaan kerja unit belum mengarah pada pengaturan teknis penyelenggaraan pelayanan masyarakat miskin, seperti lembar kartu pelayanan pasien gakin, yang merupakan kontrol baik biaya maupun penggunaan bahan habis pakai/obat berbeda penanganannya di tiap ruangan, tiap ruangan juga berbeda cara menangani sisa obat dan juga berbeda dalam pencatatan dan pelaporan. Perencanaan kerja unit dibuat berdasarkan kebijaksanaan pelaksanaan diatas yang dibuat secara tertulis oleh pimpinan unit. Perencanaan kerja unit merupakan langkah-langkah aktifitas yang memuat cara pelaksanaan, waktu dan sumber daya yang diperlukan sehingga perencanaan menjadi suatu arahan yang dapat diawasi oleh pimpinan. Pimpinan dapat mengetahui apakah perencanaan telah dilaksanakan dengan disiplin dan dapat diketahui apakah sudah sesuai dengan target tugas yang tercapai baik kuantitas maupun kualitas dari kegiatan. ${ }^{9}$

Pimpinan harus mampu membuat prosedur pelaksanaan kegiatan, dengan melihat tahapan pelaksanaan secara sitematis, berkomunikasi dengan pelaksana, bertentangan dengan prosedur yang lebih atas. Pelaksanaan penerimaan obat dan bahan habis pakai/obat yang dijalankan, tidak seluruhnya mengikuti prosedur, misalnya beberapa ruangan melakukan pencatatan ulang. Mungkin karena prosedur yang tidak tertulis dan tidak dievaluasi. Hal yang sama ditemukan pada prosedur pemberian obat pada pasien yang telah dijalankan tetapi terkadang tidak mengikuti prosedur. Beberapa ruangan hanya memastikan pemberian obat ke pasien dengan menanyakan kepada keluarga pasien dan pelaksana sebelumnya tanpa melakukan penilaian kebenarannya. Bahkan instalasi penyelenggara (IPP), belum dapat memakai lembar tersebut untuk memastikan obat telah diberikan pada pasien sesuai dengan resep dokter.

\section{Pencatatan dan Pelaporan Kerja Unit}

Dokumentasi oleh pelaksana bermanfaat banyak dan data pasien dicatat akurat dan dipakai ulang untuk keperluan lain. Perawat tidak hanya dituntut meningkatkan mutu pelayanan tetapi juga membuat dokumen yang benar. Prosedur permintaan dan penerimaan resep tidak berjalan optimal karena pada saat diperlukan lembar tersebut dapat tercecer tidak pada tempatnya. Peran perawat melakukan kontrol penggunaan dan konsumsi obat sangat diperlukan. Kegiatan tersebut harus mengikuti pola tertentu sehingga resiko kerugian dapat dihilangkan. Kegiatan tersebut berupa penjelasan rinci pengelolaan obat harus dilakukan perawat secara ketat. Misalnya papan nama di tempat tidur pasien, juga merupakan alat kontrol pemberian bahan habis pakai dan obat yang tidak selalu diisi. Ada ruangan yang melakukan pencatatan secara cermat segera setelah menanyakan dan menghitung obat, atau mencek obat yang akan dibawa pasien pulang. pengisian lengkap memudahkan pengontrolan oleh pelaksana selanjutnya sehingga pekerjaan lebih efisien dan efektif. ${ }^{10}$

Prinsip dasar suatu laporan adalah kebenaran dan kesesuaian isi kegiatan yang dilaporkan dengan keadaan kegiatan yang aktual, sehingga laporan dapat dipertanggung jawababkan. ${ }^{9}$ Pencatatan dan pelaporan kerja unit merupakan salah satu komponen pengawasan pimpinan terhadap pelaksana, sehingga pencatatan dan pelaporan perlu dipantau, diperiksa dan dievaluasi. Mengingat pencatatan dan pelaporan yang teliti, lengkap dan tepat waktu dapat dipakai untuk merencanakan kembali berbagai hak yang berhubungn dengan pasien. Hal senada juga dikemukakan oleh Kepala Instalasi Pelayanan Sosial bahwasanya ketepatan waktu pencatatan tetap menjadi prioritas utama dalam penyelenggaraan pelayanan kesehatan masyarakat miskin tapi masih tetap pada pelaksanaannya terbentur pada hari libur sehingga tidak dapat dicatat dan dilaporkan tepat waktu walaupun pelaksana dapat juga melakukannya karena sudah dilatih. Pelaksana ruangan tidak dapat melakukan pencatatan dan pelaporan kegiatan harian ruang rawat kemungkinan karena tenaga pelaksana tidak memadai dan takut melakukan kesalahan dalam pencatatan di alat komputer.

\section{Pembinaan Personil}

Pembinaan personil bidang tehnis bertujuan agar pelaksana secara terus menerus mempunyai kemampuan kerja yang sesuai dengan perkembangan. Jika perlu sosialisasi segera, kepala instalasi tetap melakukan pembinaan pada saat kunjungan ruangan. Pembinaan juga dapat dilakukan melalui asisten kepala instalasi kemudian secara berjenjang pelaksana pagi melakukan 
sosialisasi kepada pelaksana sore dan seterusnya. Hal ini memungkinkan informasi dari pelaksana terakhir tidak utuh sehingga dapat terjadi salah persepsi atau menerima sosialisasi yang salah. Ketidaksesuaian ini berdampak seperti yang terungkap pada wawancara mendalam, bahwa pelaksana yang berhubungan dengan pasien yang mengikuti sosialisasi tersebut, karena mereka tidak mengetahui secara jelas kebijakan yang sebenarnya.

\section{Faktor Kepatuhan Petugas}

Faktor kepatuhan petugas tidak lagi menjadi masalah dimungkinkan pimpinan unit sudah berupaya mempunyai atau membangun hubungan kerja dengan pelaksananya dimana dedikasi, loyalitas dan kerja sama pelaksana diharapkan. ${ }^{9}$ Pimpinan berupaya membangun dengan memberikan pelayanan administrasi kepegawaian, insentif baik materi dan non materil serta kesejahteraan dan keselamatan/keamanan dalam bekerja sehingga memotivasi pelaksana agar berprestasi. Jadi pelaksana mengetahui dampak dari tugasnya jika dilakukan dengan benar, pimpinan memberikan kemudahan dalam proses misalnya kenaikan pangkat, mengikuti seminar/pelatihan dan mungkin sampai mendapatkan penghargaan dan jika berbuat salah pimpinan mungkin memberi teguran, sanksi atau sesuatu yang dapat mengkoreksi diri sehingga untuk selanjutnya tidak lagi terjadi penyimpangan. Menurut wakil kepala instalasi rawat inap ketidakpatuhan hanya terjadi pada kedisiplinan pelaksana dalam waktu kedatangan. Kadang pelaksana datang terlambat oleh karena faktor jarak rumah yang jauh dari rumah sakit.

\section{Pengukuran Kinerja dan Pembandingan dengan Standar}

Manfaat lain pengukuran adalah bahwa pimpinan dapat megetahui penyimpangan. Namun, penyimpangan tidak selalu berkonotasi negatif yang dianggap kesalahan pengukuran dapat juga dilakukan dengan melihat penerimaan sosialisasi penyelanggaraan pelayanan. Kemungkinan pelaksana dapat lupa karena sejak awal tidak mengetahui secara jelas, atau pada saat sosialisasi tidak mencatat hanya mendengar saja atau tidak ada notulen. Dengan demikian, dalam perumusan perencanaan sangat penting adalah menentukan standar yang dipakai dan menganalisa penyimpangan karena kedua kegiatan tersebut masih asing bagi para pelaksana. ${ }^{11}$ Pengukuran dapat dilakukan melihat laporan lisan dan tulisan, catatan harian, bagan/grafik, atau dengan menggunakan peralatan tehnis yang lain seperti lembar format atau daftar check list.

Pengukuran kinerja pelaksana yang berhubungan dengan prosedur permintaan dan penerimaan bahan habis pakai/obat, dilihat pada lembar kartu pelayanan pasien gakin yang dapat mengungkapkan kinerja pelaksana yang tidak standard. Pengukuran kerja pelaksana dapat dilakukan terhadap kegiatan yang sedang atau yang te- lah dilaksanakan. Pengukuran juga dapat dilakukan dengan melihat resep yang ditulis dokter, apakah tercantum lengkap mulai nama dan paraf dokter, nama ruangan, jumlah yang diminta sampai dengan aturan pemakaian. Pada observasi terungkap masih ada resep tanpa nama dan paraf dokter serta pada saat penutupan masih ada yang menulis permintaan bahan habis pakai atau obat ditambah lagi dengan pencoretan pada bagian jumlah yang sebelumnya telah ditulis.

\section{Kepemimpinan}

Kepemimpinan seseorang dilihat dari kemampuannya mempengaruhi dan meyakinkan orang lain sehingga orang tersebut segera tergerak dan melaksanakan tugasnya. Jadi seorang pimpinan harus mempunyai karakter sehingga dapat mempengaruhi dan memberikan perhatiannya kepada petugas agar dapat bersama-sama dengannya mencapai tujuan organisasi unit yang juga direncanakannya secara bersama-sama pula. ${ }^{12}$ Perhatian yang diberikan sudah menjadi tugas rutin oleh karena harus kembali diberikan apabila terlihat petugas sudah mulai tidak produktif lagi. Hal yang sama juga dikemukakan oleh Nursalam, ${ }^{10}$ dalam menjalankan fungsi pengawasan dan evaluasi terhadap petugasnya, seorang pimpinan bukan hanya mengelola dan memimpin orang tapi juga mengelola sebuah proses sehingga secara keseluruhan dapat dilaksanakan oleh pelaksana secara efisien dan efektif.

\section{Standar}

Penentuan standar seperti adanya Prosedur Tetap Tindakan Umum Keperawatan dan Standar Asuhan keperawatan. Hal senada juga dikemukakan Al-Amin, yang menyatakan bahwa suatu proses pengawasan yang baik, pimpinan unit akan membuat/menetapkan suatu standar yang dipakai untuk menilai pelaksanaan suatu kegiatan/program. Menurut Nawawi, ${ }^{9}$ memang standar yang disebutnya tolok ukur ini merupakan standar yang ditentukan sehingga dapat menilai suatu pekerjaan sehingga nantinya tidak merugikan dan membingungkan pihak yang diawasi. Pelaksanaan pengawasan harus didukung oleh standar, yang sebaiknya dikuantitatifkan agar mudah dalam melakukan pembandingan dengan hasil kerja pelaksana oleh Harahap. ${ }^{11}$

Sedangkan untuk standar kinerja, dipakai standar dengan format penilaian kinerja, yang dilakukan bagian keperawatan dangan kepegawaian rumah sakit untuk menilai sehubungan dengan pembagian insentif pelaksana. Selain itu pelaksana juga dinilai melalui DP3, yaitu Daftar Penilaian Pelaksanaan Pekerjaan Pegawai Negeri Sipil (PNS), yang dikeluarkan oleh Departemen Dalam Negeri sehubungan dengan kinerjanya sebagai pegawai negeri sipil.

Dalam menjalankan fungsi pengawasan dan evaluasi 
petugas, seorang pimpinan harus mampu menyelenggarakan budaya pengawasan yang dilakukan secara terus menerus, karena merupakan tanggung jawab langsung pimpinan. Pimpinan harus menyadari dan memahami bahwa pengawasan yang dilakukan terus menerus (waskat) yang menjadikannya suatu budaya. Jika tidak, mustahil dapat menjalankan dan menerapkan waskat secara efisien dan efektif. Dalam mengembangkan budaya pengawasan, pimpinan harus selalu mengingatkan bahwa budaya ini tidak saja bersifat formal tapi juga informal. Prosedur yang baik dilakukan walaupun tidak ada penanggung jawab ruangan atau kepala instalasi seolaholah selalu dalam proses pemeriksaan.

\section{Koreksi}

Koreksi merupakan salah satu langkah dalam suatu proses pengawasan. Koreksi sebaiknya cepat dilakukan jika melihat adanya penyimpangan, karena tindakan koreksi tidak selalu dapat dilakukan segera, tetapi membutuhkan waktu tertentu. Jika koreksi dibutuhkan untuk perbaikan pada periode selanjutnya, maka koreksi dilakukan melalui perbaikan perencanaan atau membuat alternatif lain yang menuntut standar baru.

\section{Kesimpulan}

Pelaksanaan pengawasan di unit rawat inap RS Persahabatan tahun 2006 yang belum optimal disebabkan oleh pimpinan unit belum menggunakan sarana dan sasaran pengawasan yang ada. Belum ada pedoman pelaksanaan pelayanan yang tertulis yang dapat dijadikan panduan pelaksana. Faktor kepatuhan petugas tidak lagi menjadi kendala, tapi tetap terus mendapat perhatian pimpinan. Pemimpin unit rawat inap belum dapat menatakalsana pelaksanaan pelayanan gakin dalam pengawasan dengan optimal. Pelaksanaan pelayanan tidak seragam dan pengawasan belum membudaya. Pelaksanaan pengawasan penggunaan bahan habis pakai/obat dan pemberian obat ke pasien belum optimal karena belum ada standar yang dipakai.

\section{Saran}

Pelaksanaan pelayanan kesehatan masyarakat miskin seharusnya didukung oleh kebijaksanaan penyelenggaraan yang dibuat pimpinan berdasarkan peraturan instalasi pelaksana pelayanan tertulis yang disosialisasikan. Kebijakan pelaksanaan pelayanan gakin meliputi perencanaan teknis operasional yang mencakup pembinaan personil dan penetapan standar serta pengukuran kinerja untuk menilai keberhasilan pelaksanaan pelayanan. Perencanaan dibuat ke arah teknik opersional, yang mempermudah kegiatan pelaksana, seperti tertib administrasi prosedur tindak keperawatan, prosedur permintaan dan penerimaan bahan habis pakai dan prosedur pemberian obat. Perlu pembenahan kerja unit seperti prosedur tindak keperawatan, prosedur permintaan bahan habis pakai/obat, prosedur pemberian obat dan format baku pengembalian obat ke apotik sehingga seragam untuk semua ruangan. Perlu pembenahan pencatatan dan pelaporan kerja unit, meliputi lembar kartu pelayanan pasien gakin, asuhan keperawatan, danbimbingan pelaksana. Perlu pelatihan/sosialisasi khusus tehnis operasional penyelenggaraan pelayanan kerja sama IPP, Apotik, dan Rawat Inap dan ditekankan seluruh pelayanan masyarakat miskin dengan penanganan yang yang berbeda diarahkan pada pemecahan masalah.

Pengawasan di unit rawat inap juga harus dibudayakan dan pimpinan unit berusaha untuk memantau kegiatan secara mendadak. Dikembangkan kerja sama yang teratur antara Instalasi Rawat Inap, Instalasi Pelayanan Sosial (/IPP) dan Apotik.

\section{Daftar Pustaka}

1. Suharno, N. 2005, Stagnasi Dalam Pendanaan Program Kesehatan Masyarakat. Dalam Thabrany, H. (Ed.), 2005, Pendanaan Kesehatan dan Alternatif Mobilisasi Dana Kesehatan di Indonesia, PT Raja Gravindo Persada, Jakarta.

2. Pujiyanto, 2005, Stagnasi Pendanaan Kesehatan Sektor Publik. Dalam

3. Soejitno, S. dkk 2000, Reformasi Perumahsakitan Indonesia, Hastarimasta, Jakarta.

4. Rubi, M. 2005, Pendanaan Kesehatan Bagi Penduduk Miskin. Dalam Thabrany, H. (Ed.), 2005, Pendanaan Kesehatan dan Alternatif Mobilisasi Dana Kesehatan di Indonesia, PT Raja Gravindo Persada, Jakarta.

5. Thabrany, H. (Ed.), 2005, Pendanaan Kesehatan dan Alternatif Mobilisasi Dana Kesehatan di Indonesia, PT Raja Gravindo Persada, Jakarta.

6. http://drarifianto.multiply.com/2 maret 2006

7. Muninjaya, G. 2004, Manajemen Kesehatan, Edisi ke 2, Penerbit EGC, Jakarta.

8. Peddyawati, E. 2005, Analisa Proses Penagihan Piutang Pasien JPK Gakin Rawat Inap di RS Persahabatan, Tesis KARS-FKM Univ. Indonesia, Jakarta.

9. Nawawi, HH. 1992, Pengawasan Melekat Di Lingkungan Aparatur Pemerintah, Cetakan ke 2, PT. Gelora Aksara Pratama, Penerbit Erlangga, Jakarta.

10. Nursalam, (2002), Manajemen Keperawatan Aplikasi Dalam Prakik Keperawatan Profesional, Salemba Medika, Edisi I, Jakarta

11. Harahap, SS. 2004, Sistem Pengawasan Manajemen (Management Control System), Cetakan ke 2, P.T Pustaka Quantum, Jakarta

12. Ilyas, Y. (2002), Kinerja, Teori, Penilaian, Dan Penelitian, Pusat Kajian Ekonomi kesehatan FKM Universitas Indonesia, Cetakan ke 3, Depok. 